\title{
Evaluation of 865 children who underwent magnetic resonance imaging under propofol-midazolam sedation
}

\section{Propofol-midazolam sedasyonu altında magnetik rezonans görüntüleme yapılan 865 çocuk hastanın değerlendirilmesi}

\author{
Gülsen KESKiN, Mine AKIN, Yeşim ŞENAYLI, Sibel SAYDAM, Sengül ÖZMERT, Devrim Tanıl KURT, Feyza SEVER
}

\section{ABSTRACT}

Implementation of sedatives during magnetic resonance imaging (MRI) in pediatric patients is often preferred. Propofol and midazolam are mostly chosen drugs, and it is suggested that these drugs have synergistic effects. However, studies with large populations in order to observe the possible complications of this combination are very few. In this study we aimed to evaluate the effectiveness, side effects, complications in 865 children undergoing MRI with propofol-midazolam sedation. Anesthesia charts of 865 children sedated for MRI between January 2010 and December 2015 were analyzed retrospectively. Standardized sedation protocol was used. General features, demographic parameters and complications were recorded. Results were compared and discussed in the light of the literature. Median age of the patients was 3.01 years, and $89.2 \%$ of the patients were classified in ASA II-III risk groups. While $79.9 \%$ of the patients had neurological impairment. Respiratory depression, bradycardia, allergic reactions and hiccup were recorded, and these side effects were seen in $1.9 \%$ of the patients. Respiratory depression was the mostly seen complication. In pediatric patients usage of a standard propofol and midazolam regimen is a very effective method with a lower complication rate. Effectiveness was nearly 98\%. Allergic reactions and hiccup were very rare. When compared with literature, it seems that rates and types of complications will increase with escalating number of patients. We can also pronounce that ASA risk classification is not a predictive factor to decide whether or not to perform MRI examination under anesthesia.

Keywords: Child, magnetic resonance imaging, midazolam, propofol

\section{öz}

Çocuklarda, manyetik rezonans görüntüleme (MRG) sırasında sedasyon uygulamak genellikle yeğlenen bir uygulamadır. Propofol ve midazolam en çok yeğlenen ilaçlardır ve sinerjistik etkileri nedeniyle önerilmektedir. Ancak, bu uygulama sırasında karşılaşılabilecek komplikasyonlar için geniş populasyonlu gözlemsel çalışma azdır. Çalışmamızda, propofol-midazolam sedasyonu ile MRG yapılan 865 çocuk hastadaki etkinlik, yan etki ve komplikasyonların değerlendirilmesi amaçlanmıştır. Ocak 2010-Aralık 2015 tarihleri arasında MRG için sedasyon uygulanan 865 pediatrik hastanın anestezi formları retrospektif olarak analiz edildi. Hastalara standart sedasyon protokolü uygulandı. Demografik veriler ve komplikasyonlar kaydedildi. Sonuçlar literatür eşliğinde tartışıldı. Hastaların ortanca yaş değeri 3.01 idi. ASA II-III sInıflandırması olan hastalar populasyonun \%89,2 idi. Hastaların $\% 79,9$ 'unun nörolojik hastalığı vardı. Solunum depresyonu, bradikardi, alerjik reaksiyonlar ve hıçkırık gibi yan etkiler \%1,9 hastada görüldü. Desatürasyon en sık görülen solunum komplikasyonu idi. Bu çalışmada, çocuk hasta populasyonunda standart olarak uygulanmış propofol-midazolam kombinasyonu ile \%98'lere ulaşan etkinlik ve düşük komplikasyon oranları gösterilmiştir. Allerjik reaksiyonlar ve hıçkırık gibi komplikasyonlar çok az görülmüştür. ASA risk sınıflandırmasının MRG için sedasyon uygulanıp uygulanmayacağı açısından karar verdirici olmadığı çalışmamıza göre söylenebilir.

Anahtar kelimeler: Çocuk, manyetik rezonans görüntüleme, midazolam, propofol

\section{INTRODUCTION}

Sedation procedures during magnetic resonance imaging (MRI) are raising new challenges for anesthesiologists ${ }^{1}$. Oral, rectal or intramuscular narcotics and barbiturates are occasionally inadequate to ensure a proper sedation without movement for children especially with mental retardation ${ }^{1-4}$. In addition, MRI is a noninvasive but a noisy study, and patient must be completely immobile to obtain a good image ${ }^{1-4}$. Because of these reasons, sedation or general anesthesia is needed ${ }^{1-4}$. At this stage, the selected anest-

Received: 04.08.2017

Accepted: 14.08.2017

Department of Anesthesiology, University of Health Sciences, Ankara Child Health and Diseases Hematology Oncology Training and Research Hospital, Ankara, Turkey

Yazışma adresi: Gülsen Keskin, Department of Anesthesiology, University of Health Sciences, Ankara Child Health and Diseases Hematology Oncology Training and Research Hospital, Ankara, Turkey

e-mail: drgulsenkeskin@gmail.com 
hetic agent must be a fast-acting sedative and recovery must be in a short time ${ }^{3,5,6}$. Besides, the selected drug must have no adverse effects like vertigo, nausea and vomiting that may cause prolonged hospitalization. Seizure threshold must not be altered during the usage of this drug.

There are different reports about various sedative agents used in MRI studies ${ }^{7}$. Mostly preferred agents are pentobarbital, dexmedetomidine, propofol and midazolam ${ }^{7}$. Propofol has rapid induction, better recovery and quick catabolism without redistribution. It is usually the first-line drug for outpatient anesthesia procedures which does not cause nausea and vomiting ${ }^{3}$. However, the disadvantages are respiratory and hemodynamic depression, shorter duration of effect, dose-dependent effect, and absence of any antagonist drug ${ }^{8}$. Midazolam is used especially for its amnesic, anxiolytic and short acting effects. It was reported that propofol and midazolam had synergetic effects ${ }^{6,8}$. It was suggested that synergetic effect was originated from interactive relationship among gamma-aminobutyric acid receptors ${ }^{6}$. This synergism causes alteration in propofol treatment and also adverse effects are decreased by this mechanism ${ }^{4}$.

There are reports about combination of propofol and midazolam at the pediatric age group in the literature. However, number of patients were not sufficient to make a decision, and meanwhile other drugs added in this combination hindered obtaining a clear result concerning the risks and effectiveness of propofolmidazolam treatment ${ }^{3,9}$. As a result, debates are going on. Our study yielded similar outcomes with the studies of Machata et al. ${ }^{3}$, and Malviya et al. ${ }^{10}$. Although, adequately higher number of patients were enrolled in their study, data about the characteristic features of propofol-midazolam were not clearly demonstrated in this study ${ }^{10}$.

To the best of our knowledge, this serial has the largest population with 865 patients aiming to investigate the effectiveness and complications of propofolmidazolam combination in a standard and uniform protocol.

\section{MATERIAL and METHOD}

After the approval of local ethics committee (protocol \#:2015/013, dated May 27, 2015, anesthesia and clinic charts of 865 children (0-18 years) sedated during MRI performed between January 2010 and December 2015 were evaluated retrospectively. Demographic parameters, ASA risk classifications, primary diseases, MRI evaluations and durations of imaging, anesthesia complications and adverse effects were evaluated.

Patients were evaluated in anesthesia department one day before MRI, and written informed consents were obtained. Precautions were elaborated according to ASA risk classifications. In the MRI department intravenous fluid was administered. Electrocardiography, noninvasive arterial blood pressure and peripheral oxygen saturations were monitored in a standard protocol, and oxygen was delivered at a rate of $4 \mathrm{~L} / \mathrm{min}$ with face masks. After patients' stabilizations and securities were ensured, midazolam $\left(0.1 \mathrm{mg} \mathrm{kg}^{-1} \mathrm{IV}\right.$; max. $2.5 \mathrm{mg}$ ) (Zolamid ${ }^{\circledR}$, Defarma, Turkey) and propofol (2 $\mathrm{mg} \mathrm{kg}^{-1} \mathrm{IV}$; Propofol \%1 Fresenius ${ }^{\circledR}$ vial, Fresenius Kabi, Austria) were administered. When Ramsay sedation scores (RSS) were 5 or greater, MRI was performed. Respiratory functions were especially monitored for depression. Airway and shoulder scrolls were used for the patients with hypoventilation. Secretions were aspirated. If aspiration failed, atropine was used. Endotracheal tubes were prepared for a probable emergency intubation. If patients made movements during imaging, propofol ( $1 \mathrm{mg} \mathrm{kg}^{-1} \mathrm{IV}$ ) was given. If the duration of imaging was longer than 30 minutes, propofol infusion was planned at a dose of $2 \mathrm{mg} \mathrm{kg}^{-1} \mathrm{~h}^{-1}$. After the examinations, patients were taken to the recovery room. Patients were sent home after RSS were 3 and lower. In addition, oral intakes and general conditions were observed to make decisions for discharges.

Similar articles were found for discussion. Only in one article our evaluation criteria were used. Therefore, we paid maximum attention to find out similar data in some other articles, and we excluded suspicious data even if the data seemed to be useful for consideration in this article. 


\section{Statistical Evaluation}

Definitions of variables were performed where available. Predictive factors for complications like age, gender, weight, ASA risk classes, diagnosis and duration of the imaging were evaluated with univariate and multivariate regression analysis. $\mathrm{P}<0.05$ was accepted as statistically significant. SPSS 17 (Chigago, USA) program was used for statistical assessments.

\section{RESULTS}

A total of 865 children between $0-18$ years of age were evaluated for sedation procedures from January 2010 to December 2015. Demographic parameters of patients and ASA risk classifications are given in Table 1. The youngest patient was 10 days old, weighed $2300 \mathrm{~g}$ with ASA IV and cranial MRI was performed with the indication of intractable seizures. Majority $(79.9 \%)$ of the patients had primary neurological diseases as shown in Table 2.

Table 1. Demographic parameters of patients and ASA risk classification.

\begin{tabular}{lll}
\hline & Median Age & Range \\
\hline Age (Year) & 3.01 & $1-14$ \\
Weight (kg) & 14.3 & $2-84$ \\
\hline & Patients (n=865) & Percentage (\%) \\
\hline Gender (n) (M/F) & $512 / 353$ & $59.2 / 40.8$ \\
ASA I (n) & 83 & 9.6 \\
ASA II (n) & 515 & 59.5 \\
ASA III (n) & 257 & 29.7 \\
ASA IV (n) & 10 & 1.2 \\
& & \\
\hline
\end{tabular}

Table 2. Disease systems of the patients and percentages.

\begin{tabular}{lll}
\hline Disease Systems & Patients $(\mathbf{n})$ & Percentage (\%) \\
\hline Neurology & 691 & 79.9 \\
Oncology & 77 & 8.9 \\
Genetics & 31 & 3.6 \\
Endocrinology & 21 & 2.4 \\
Immunology & 14 & 1.6 \\
Metabolic & 17 & 2.0 \\
Hematology & 14 & 1.6 \\
& & \\
\hline
\end{tabular}

Cranial MRI was the most frequently used imaging modality in $85.2 \%$ of the cases, and procedural times are shown in Tables 3 and 4.

Table 3. Regions evaluated with MRI.

\begin{tabular}{lll}
\hline & MRI (n) & Percentage (\%) \\
\hline Cranial & 737 & 85,2 \\
Cranial Spectroscopy & 20 & 2,3 \\
Spinal & 38 & 4,4 \\
Extremity & 17 & 1,9 \\
Abdomen & 18 & 2,1 \\
Thorax & 5 & 0,6 \\
Cranial\& complete spinal & 30 & 3,5 \\
& & \\
\hline
\end{tabular}

Table 4. Duration of MRI examinations.

\begin{tabular}{lll}
\hline Duration (min) & Patients (n) & Percentage (\%) \\
\hline 20 & 736 & 85.1 \\
30 & 23 & 2.7 \\
40 & 55 & 6.4 \\
$60 \& \uparrow$ & 41 & 4.6 \\
\hline
\end{tabular}

Table 5. Complications.

\begin{tabular}{lll}
\hline Complications & Patients (n) & Percentage (\%) \\
\hline Respiratory Depression & 9 & 1 \\
Bradycardia & 4 & 0.5 \\
Allergic Reaction & 3 & 0.3 \\
Hiccup & 1 & 0.1 \\
With no complication & 848 & 98 \\
& & \\
\hline
\end{tabular}

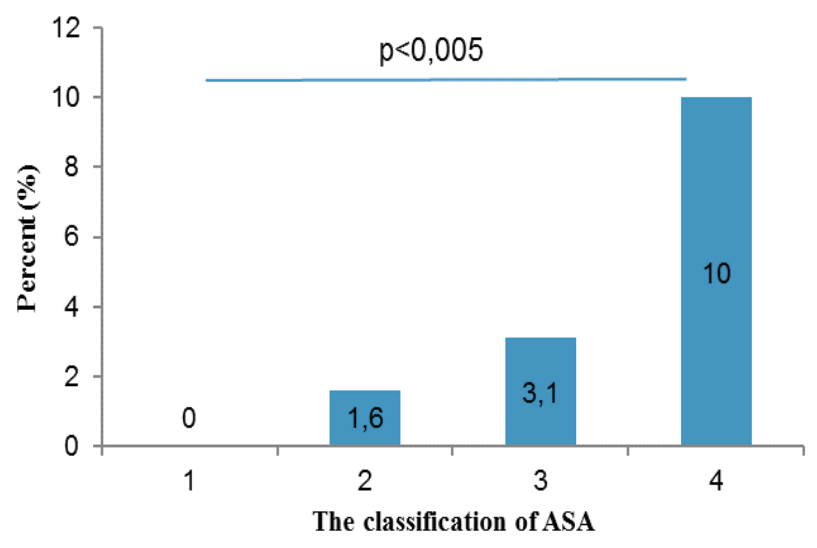

Figure 1. Distribution of complications according to ASA risk classification. 
Two MRI examinations were terminated prematurely because of bronchospasm and head tilting. Except for these two patients, MRI was successfully performed in $99.7 \%$ of the cases. There were major complications and whole complication rate was $1.9 \%$. Desaturation was the most common complication and it was seen in $4(0.56 \%)$ patients (Table 5$)$. Respiratory depression was seen in $1.0 \%$ of the patients. Flumazenil (Anexate ${ }^{\circledR}$, Deva, Istanbul, Turkey) was used to handle respiratory complications. According to ASA risk classifications, complications were mostly seen in ASA IV patients $(p<0.005)$ (Figure 1$)$. Median recovery time was $22.7 \pm 4.1$ minutes. None of the patients were intubated.

\section{DISCUSSION}

$\mathrm{MRI}$ is an important radiological method in the diagnosis, treatment and follow-up of the patients. In addition, the importance of MRI augments after adding anesthesia facilities to this method. New imaging protocols have been specifically developed with the assistance of anesthesiologists in order to make successful MRI scans for babies and children ${ }^{3,5}$.

Fast-acting anesthetic agents are mostly chosen drugs for $\mathrm{MRI}^{7}$. Leading agents in this issue are dexmedetomidine, propofol, midazolam, pentobarbital and sevoflurane ${ }^{7}$. However, the fast-acting features of these agents are not enough. A suitable agent must achieve supreme sedation, anxiety control, strong amnesia, immobility, rapid recovery and least psychogenic trauma for successful MRI examinati$\mathrm{on}^{3}$. In a study, it was stated that anesthetic agents had no significant difference as for sedative potency among each other?.

Propofol is the mainly preferred agent for outpatient practice ${ }^{4,6,11}$. One of the reason to choose propofol is its negligible effects on cortical functions ${ }^{7}$. Therefore, propofol is the most commonly used intravenous anesthetic agent for the sedation of pediatric patients $^{12}$. Anesthesia induction depends on continuity of the dose and respiratory and hemodynamic depression may be seen ${ }^{4,6,8}$. In addition, propofol does not have its antagonist ${ }^{4,6,8}$.

Midazolam has very similar anesthetic efficiency with propofol ${ }^{13}$. It is preferred especially for its amnesic and anxiolytic effects, and it has a short-acting effect $^{6,11}$. Midazolam decreases disadvantages of propofol and recovery time and discharge from hospital is shortened with midazolam-propofol combination ${ }^{8}$. In a study, it was proved that midazolam decreased total induction dose of propofol at a rate of $23 \%{ }^{4}$. Basic mechanism of this association is not clear but gamma-aminobutyric acid receptors are supposed to be mediators for this mutual effect ${ }^{6}$.

Sedation or anesthesia management in diagnostic studies of children causes emergence of undesirable effects in $20 \%$ of the patients, and most of them (5.5\%) consist of respiratory problems ${ }^{14,15}$. Machata et al. ${ }^{3}$ reported that respiratory problems were seen in $1 \%$ of their patients in their trial. In another study, propofol was administered in 50 patients and did not result in cardiac and respiratory problems ${ }^{1}$. Also, Havel et al. ${ }^{16}$ reported that hypotension was not seen in their study. Contrary to the information like these, Usher et al. ${ }^{17}$ reported that at the time their report was written, patient population was not sufficient to put forward data especially about respiratory and cardiac problems. In this study, one of 93 patients was treated with a minor manipulation for respiratory problem (putting a padding on the back), and one patient was treated with placement of an oral airway ${ }^{17}$. In our study, the common problem was desaturation ( $n=4,0.56 \%$ ). Simple manipulations like aspiration and oral airway placement for these patients were sufficient for treatment. Desaturation was seen in all patients with primary neurologic disorders and they all had oral defects. Periods of bradycardia were detected in 2 patients $(0.28 \%)$ which did not cause serious problems.

Our study is very similar with the study of Machata et al. ${ }^{3}$. Allergic reactions and hiccup were not found in that study ${ }^{3}$. In our study allergic reactions and hiccup were present. These two problems were rarely defined in other studies. The problems might be seen 
coincidentally. On the other hand, it might be related to the propofol and midazolam combination. According to us, allergic reactions and hiccup may be seen in the larger-scale studies.

Head movement is one of the restrictive aspects on the success of MRI examination ${ }^{17}$. Intravenous propofol and nasal oxygenation are usually effective in stopping head movements, thus successful MRI examination can be achieved ${ }^{17}$. In our study, there was only one patient who repeatedly moved his head during MRI examination.

ASA III-IV patients were evaluated in a special group especially for outpatient procedures like MRI examinations. In the literature, ASA I-II patients are found eligible for MRI in general ${ }^{4}$. We did not compare some of the studies performed on ASA III-IV patients sedated during MRI examinations because sedation protocols of these patients were not clear for $u s^{10}$. ASA guidelines and related local guidelines are sufficient to provide optimum monitoring and equipment according to patients' circumstances ${ }^{18,19}$. Machata et al. ${ }^{3}$ evaluated 500 ASA I-II patients sedated with propofol. In this study propofol was used for sedation of the highest number of pediatric patients studied so far.In some articles like that of Machata et al. ${ }^{3}$ patients with ASA III-IV risk classification were excluded from the study ${ }^{5}$. To our knowledge, ASA IV patients were sedated for MRI examination only in our study. A total of 267 ASA III-IV patients were sedated in our study. Not surprisingly, most of the complications were seen in ASA IV patients.

In conclusion, propofol-midazolam combination is a suitable selection to be used during MRI scans ${ }^{1}$. Our study revealed as in some other studies that propofol-midazolam combination can provide protection of respiration with lower incidence of adverse effects and complications in newborns, infants and older ages. In addition, ASA III-IV risk classifications do not provide definitive criteria for the indication of MRI scan. In our study, a significant increase in the number of complications related to ASA classification was present but all of them were slight comp- lications which resolved with minor manipulations. Finally, this is the largest study focused on the use of only propofol-midazolam combination in the pediatric age group. Therefore, we can state that ours is an exceptional study so far.

\section{REFERENCES}

1. Lefever E, Potter PS, Ley NR. Propofol sedation for pediatric MRI. Anesth Analg 1993;76:919-20.

https://doi.org/10.1213/00000539-199304000-00071

2. Starkey E, Sammons HM. Sedation for radiological imaging. Arch Dis Child Educ Pract Ed 2011;96:101-6. https://doi.org/10.1136/adc.2008.153072

3. Machata AM, Willschke $H$, Kabon B, et al. Propofol-based sedation regimen for infants and children undergoing ambulatory magnetic resonance imaging. British Journal of Anaesthesia 2008;101:239-43. https://doi.org/10.1093/bja/aen153

4. Djaiani G, Ribes-Pastor MP. Propofol auto-co-induction as an alternative to midazolam co-induction for ambulatory surgery. Anaesthesia 1999;54:51-85. https://doi.org/10.1046/j.1365-2044.1999.00658.x

5. Gullo A. Sedation and anesthesia outside the operating room: Definitions, principles, critical points and recommendations. Minerva Anestesiol 2005;71:1-9.

6. Seifert H, Schmitt TH, Ltekin TG, et al. Sedation with propofol plus midazolam versus propofol alone for interventional endoscopic procedures: A prospective, randomized study. Aliment Pharmacol Ther 2000;14:1207-14. https://doi.org/10.1046/j.1365-2036.2000.00787.x

7. Bernala B, Grossman S, Gonzalez R, et al. fMRI under sedation: What is the best choice in children? J Clin Med Res 2012;4:363-70. https://doi.org/10.4021/jocmr1047w

8. Kerker A, Hardt C, Schlief HE, et al. Combined sedation with midazolam/propofol for gastrointestinal endoscopy in elderly patients. BMC Gastroenterology 2010;11:1-5. https://doi.org/10.1186/1471-230X-10-11

9. Padmanabhan U, Leslie K, Eer AS, et al. Early cognitive impairment after sedation for colonoscopy: The effect of adding midazolam and/or fentanyl to propofol. Anesth Analg 2009;109:1448-55.

https://doi.org/10.1213/ane.0b013e3181a6ad31

10. Malviya S, Voepel-Lewis T, Eldevik OP, et al. Sedation and general anesthesia in children undergoing MRI and CT: Adverse events and outcomes. BJA 2000;846:743-8. https://doi.org/10.1093/oxfordjournals.bja.a013586

11. Küçükyavuz Z, Cambazoglu M. Effects of low-dose midazolam with propofol in patient-controlled sedation (PCS) for apicectomy. Br J Oral Maxillofac Surg 2004;42:215-20. https://doi.org/10.1016/j.bjoms.2004.01.005

12. Sury MR, Smith JH. Deep sedation and minimal anesthesia. Paediatr Anaesth 2008;18:18-24.

13. Carrasco G, Molina R, Costa J, et al. Propofol vs midazolam in short-medium-, long-term sedation of critically III patients. A cost-benefit analysis. Chest 1993;103:557-64. https://doi.org/10.1378/chest.103.2.557

14. Malvia S, Voepel-Lewis T, Trait AR. Adverse events and risk factors associated with the sedation of children by nonanesthesiologists. Anesth Analg 1997;85:1207-13. 
https://doi.org/10.1213/00000539-199712000-00005

15. Cravero JP, Blike GT, Beach $M$, et al. The incidence and nature of adverse events during pediatric sedation/anesthesia with propofol for procedures outside the operating room: A report from the pediatric sedation research consortium. Anesth Analg 2009;108:795-804. https://doi.org/10.1213/ane.0b013e31818fc334

16. Havel CH Jr., Strait RT, Hennes H. A clinical trial of propofol vs midazolam for procedural sedation in a pediatric emergency department. Acad Emerg Med 1999;6:989-97. https://doi.org/10.1111/j.1553-2712.1999.tb01180.x
17. Usher AG, Kearney RA, Tsuı BCH. Propofol total intravenous anesthesia for MRI in children. Ped Anesth 2005;15:23-8. https://doi.org/10.1111/j.1460-9592.2004.01390.x

18. ASA "Standards For Basic Anesthetic Monitoring." Standards for Basic Anesthesia Monitoring (Last Amended October 21, 1998. Park Ridge, II: American Society of Anesthesiologists, 2001.

19. Youn AM, Ko YK, Kim YH. Anesthesia and sedation outside of the operating room. Korean J Anesthesiol 2015;68:323-33. https://doi.org/10.4097/kjae.2015.68.4.323 